\title{
The Fallen Soldier as Fascist Exemplar: Military Cemeteries and Dead Heroes in Mussolini's Italy
}

\author{
HANNAH MALONE \\ University of Groningen, Faculty of Arts, Groningen, Netherlands
}

THE FALLEN SOLDIER AS FASCIST EXEMPLAR

\begin{abstract}
A corrupt society needs the Man who can restore it with his example - a population that had been thus educated will be healthy and strong, and able to conduct a war and a revolution to good end. ${ }^{1}$
\end{abstract}

In Italy, Fascist morality drew heavily on admirable models, or figures which might be real or imaginary, and whose attitudes and deeds were to be admired and imitated. ${ }^{2}$ Those models gained their identity by means of narratives that highlighted inherent values in their behavior with respect to the state. Given that morality implies "conduct in relation to [either] esteemed or despised human qualities," those exemplars were benchmarks for virtues that were expressed in the form of images and paradigms rather than rules. ${ }^{3}$ Moreover, due to its violent and repressive nature, Italian Fascism was heavily dependent on persuasion and the role played by exemplars. ${ }^{4}$ In that the Fascist regime could not rely wholly on coercion or blind obedience, it legitimized state policies and actions through the

Acknowledgments: I am grateful to Paolo Heywood, Adam Reed, and all participants in the workshop "Fascist Exemplars: Past and Present," held at the University of Cambridge in 2019. I am indebted to the editors of CSSH, Geneviève Zubrzycki, Paul Johnson, and David Akin, and to the journal's anonymous reviewers for their helpful feedback on this article. I also wish to acknowledge the financial support of the ERC grant "Situating Free Speech: European Parrhesia in Comparative perspective" (no. 683033).

1 Una società corrotta ha bisogno dell'Uomo che la risollevi con l'esempio ... Il popolo così educato è un popolo sano e forte che può condurre una guerra ed una rivoluzione a buon fine, Attilio Fuiano, Credo nella Resurrezione degli Eroi (Milan: Corticelli, 1941). All translations are the author's unless otherwise specified.

2 Rodney Needham, Exemplars (Berkeley: University of California Press, 1985), 1.

3 Caroline Humphrey, "Exemplars and Rules: Aspects of the Discourse of Morality in Mongolia," in Signe Howell, ed., The Ethnography of Moralities (London: Routledge, 1997), 25.

4 Claudia Koonz, The Nazi Conscience (Cambridge: Harvard University Press, 2003), 1. 
creation of a highly orchestrated sense of good and evil. Thus, given their capacity to enthuse and motivate, Fascist exemplars were ideal bases of moral authority.

In particular, soldiers who fell in the First World War, together with others who were seen to have died for the nation, were a major source of Fascist exemplars in that they represented older traditions of military heroism, while satisfying new needs through which heroism was closely associated with a spirit of sacrifice. Official propaganda presented fallen soldiers as role models in order to encourage patriotic feelings favorable to the regime. In that respect, a group of Fascist ossuaries that were built to rehouse the remains of soldiers who had fallen in the First World War presents a clear opportunity to examine how the regime used the fallen soldier as an exemplar. In effect, the key purpose of the ossuaries was to exploit the example of the dead in order to foster nationalism, militarism, and imperialism. In this sense, the creation of the ossuaries illustrates how the practice of exemplarity worked, what it achieved for the regime, and how it contributed to a morality suited to Fascism. However, in order to understand how the ossuaries functioned with regard to the morality and ambitions of the Fascist state, it is first necessary to explore the role of the fallen soldier as an archetypical exemplar, and how the dead were appointed as a fount of propaganda aimed at the reinforcement of morality and of practices that drew their legitimacy from both history and new political devices.

\section{FALLEN SOLDIERS AS EXEMPLARS}

For Fascism, morality was an ideological and practical necessity in part because it served to legitimize social and political conditions that were relatively extreme and included a high degree of brute force. In an article of 1921 entitled "Morality," Mussolini claimed that the death of Fascists in violent attacks against opponents was "proof" that such attacks were "rational" and "legitimate." 5 Thus, even in the early years of Italian Fascism, the dead emerged as exemplars and their willingness to die was taken as evidence of the justness of a cause. As Fascist ideology took the form of a political faith that gave moral authority to the state, it placed its interests above the rights of individuals and other nations. As indicated by the philosopher Giovanni Gentile, morality meant the self-sacrifice of the individual and the suppression of private ambitions and feelings. ${ }^{6}$ By giving power to the state, Fascism was also intended to generate a state based on discipline and an evident moral order. In short, for Mussolini, morality was "that

5 "Ragionante, razionale," "legittime," "prova," "testimonianza," Benito Mussolini, "La Morale," in Il Popolo d'Italia (19 Apr. 1921), repub. in Opera Omnia, xvi: 270-71, 270. On Fascist morality, see also Ruth Ben-Ghiat, Fascist Modernities: Italy, 1922-1945 (Berkeley: University of California Press, 2001), 8.

6 Giovanni Gentile, "Il Problema Morale," in Discorsi di religione (Florence: Sansoni, 1957), 75-107; "L'Etica Come Legge,” Genesi e Struttura della società (Florence: Sansoni, 1946), 1-10. 
which gives the law force and the state the right to demand obedience of its citizens."

Moral norms in the European, and idealistic, tradition tend to follow three principles: they are consistent, clear, and the same for everyone. ${ }^{8}$ On all three counts, such norms were not suited to Fascism as an ideology that accommodated populism, social division, and an opportunistic form of decision-making, and which was also centered on an idea of national differences rather than universal principles. Conversely, for various reasons, exemplars offered the perfect vehicle for a Fascist morality. Emerging as a relative latecomer among political ideologies, Fascism may be defined in terms of its opposition to liberalism, socialism, and communism, and as a movement driven by action and leadership rather than by political theory. ${ }^{9}$ As Mussolini stated, "The fist is the synthesis of our [Fascist] theory." 10 Instead of a fixed program of stated aims, Fascism pursued an evolving set of goals. In that respect, narratives relating to exemplary behavior that left moral principles unarticulated and open to interpretation were better than fixed codes, in that they reflected a preference for "moral action" over contemplative or "abstract maxims." 11 Thus, as an exemplar of Fascist morality the fallen soldier expressed the emphasis placed on feeling rather than on logic or codes. Moreover, Fascism foregrounded the idea of a national and moral regeneration, political and economic renewal, and the emergence of a reformed society. ${ }^{12}$

The role of exemplars as figures whose attitudes and behavior should be imitated also suited Fascism as an ideology that promoted its own brand of elitism. The emphasis on imitation and obedience suited the stress placed on the strength and will of Mussolini as a leader who led by example, and who was the primary exemplar for "the formation of a new moral character." ${ }^{13}$ As a model from which others might be derived, and as an idealized Fascist, Mussolini was male, strong, and charismatic, and when dressed in a military uniform he was an exemplar from which an image of the ideal soldier might be spun. The extent to which Mussolini cultivated his associations with the military indicates the significance of the fallen soldier, and of the ossuaries. In addition, in that the exemplar may be defined in terms of an opposition to negative or counteractive

\footnotetext{
${ }^{7}$ Benito Mussolini, Scritti e Discorsi, VII (Milan: Ulrico Hoepli, 1934) 104: "Non si pensi di negare il carattere morale dello stato fascista ... che cosa sarebbe lo stato se non avesse un suo spirito, una sua morale, che è quella che da' la forza alla legge sua e per la quale essa riesce a farsi ubbidire dai cittadini?" This quote appears in a collection of Mussolini's speeches and writings dating between 1929 and 1931 .

8 Humphrey, "Exemplars and Rules," 34.

9 Robert O. Paxton, The Anatomy of Fascism (London: Penguin, 2005), 17-18.

${ }^{10}$ Ibid., 17.

11 Giovanni Gentile, "Problema Morale," 88.

12 Roger Griffin, The Nature of Fascism (London: Pinter, 1991), 32-36.

13 "Nella formazione di un nuovo carattere morale," La Rivolta Ideale; Prefazione di Benito Mussolini (Bologna: Licinio Cappelli Editore, 1924), 371-72.
} 
forces, the ideal Fascist soldier presented as a warrior engaged in a "struggle between good and evil." "In that respect, Fascist exemplars served to distinguish a society bound together by Fascism from enemy or alien forces, and to draw boundaries between the Fascist state and its antagonists.

\section{ITALY'S EXEMPLARY DEAD}

Given that the dead naturally inspire a reverence that silences criticism, "necroexemplarity" (to use Francisco Ferrándiz's term) is common to different cultures. Renaissance humanism looked to a form of secular immortality through the remembrance of illustrious figureheads. Similarly, the Enlightenment advocated commemoration as a source of morals associated with worthy figures of earlier generations. Due to the value placed on war, heroism, and sacrifice, Italian Fascism found its perfect exemplar in the dead soldier. In casting the fallen soldier as a key exemplar, the Fascists did not entirely invent a new political mechanism or tool of propaganda, rather they drew on traditions of European and Italian nationalism. ${ }^{15}$ Since the late eighteenth century, emerging nation-states took charge of the burial of the fallen in order to draw political capital from the respect due to those who died for the national cause. Already an established model of patriotism, militarism, and masculinity, the figure of the fallen soldier was particularly suited to Fascism. At the same time, Fascism also benefitted from Italy's deep-rooted culture of patriotic commemoration. ${ }^{16}$ From the late $1700 \mathrm{~s}$, the commemoration of national heroes emerged as one of the key ideological vehicles for the various movements that contributed to the gradual emergence of Italian nationalism, to the struggle for independence or Risorgimento, and eventually to the establishment of a unified Italy. ${ }^{17}$ Those earlier movements honored those who died in the various attempts to liberate Italy. For instance, propaganda generated by the patriot Giuseppe Mazzini (1805-1872) refers to "martyrs" for the fatherland. Equally, martyrdom was an essential component of the Risorgimento as the "resurrection" of the nation. ${ }^{18}$ In the context of Italy's tormented fight for freedom, the efficacy of martyrdom lay

14 Gentile, "Problema Morale," 81; Paul Fussell, The Great War and Modern Memory (Oxford: Oxford University Press, 2013[1975]), 83.

15 Thomas W. Laqueur, The Work of the Dead: A Cultural History of Mortal Remains (Princeton: Princeton University Press, 2015), 416.

16 Alberto Tenenti, Il Senso Della Morte e l'Amore della Vita nel Rinascimento: Francia e Italia (Torino: Einaudi, 1957), 21-47; Laqueur, Work of the Dead, 182-215.

17 Roberto Balzani, “Alla Ricerca della Morte Utile': Il Sacrificio Patriottico nel Risorgimento," in Oliver Janz and Lutz Klinkhammer, eds., La Morte per la Patria: La Celebrazione dei Caduti dal Risorgimento alla Repubblica (Rome: Donzelli, 2008): 3-21; Lucy Riall, "Martyr Cults in Nineteenth-Century Italy," Journal of Modern History 82, 2 (2010): 255-87, https://doi.org/10.1086/ 651534; Hannah Malone, Architecture, Death and Nationhood: Monumental Cemeteries of Nineteenth-Century Italy (London: Routledge, 2017), 104-18.

18 Death was not a necessary condition to qualify as a martyr, since the label extended to those who dedicated their lives to the cause and as a result suffered illness, incarceration, or persecution. 
in a capacity to convert past failures into moral victories. The value of the patriotic cause was evidenced by the death of those who fought for that cause. In part, there was an underlying obsession with the Romantic idea of a meritorious death, and attitudes that were borrowed from Catholicism, although martyrdom appealed to all parts of the movement for independence, including anticlerical factions that saw the spirit of patriotism as an alternative to religion. ${ }^{19}$

After the unification of Italy in 1861, martyrdom lost its associations with rebellion. In time, it was absorbed into the official ideology of the Italian state and used to help gather the population behind the idea of Italy as one nation. Having been divided since the early Middle Ages, Italy remained deeply fragmented after 1861, while its new rulers were faced with the need to forge a common history, memory, and identity. ${ }^{20}$ As such, remembrance was seen as necessary to the moral health of the nation. For example, the funerals and entombment of worthy citizens were employed as instruments of propaganda, and in cemeteries across Italy monuments and elaborate tombs were created for the honorable burial of national heroes. Many of them were exhumed and reburied with the aim of converting the new nation to patriotism as a "religion of the fatherland" (religione della patria).

As part of the bedrock of Italian nationhood, the celebration of the dead as patriotic exemplars was passed down from the Risorgimento to Liberal and then to Fascist Italy. Meanwhile, the potential to exploit a cult of the dead, or to use martyrdom as a political mechanism, was augmented by the significant losses that resulted from the First World War, which left most Italian families in mourning and thereby created a large audience whose emotions might be manipulated. After Mussolini's rise to power in 1922, commemoration and patriotism were subjected to greater state control as allied keystones of Fascist propaganda. ${ }^{21}$ Fascist efforts to harness commemoration were reinforced as the regime coopted older Catholic and patriotic practices and drew on images and concepts that were familiar to Italians. In addition, the regime honored various groups who were seen to have died for Italy as "martyrs," including heroes of the Risorgimento, fallen soldiers of the First World War and of Italy's colonial wars, and Fascists who died in the initial struggle for power. ${ }^{22}$ For Mussolini, that Fascism

19 Alberto Mario Banti, La Nazione del Risorgimento: Parentela, Santità e Onore alle Origini dell'Italia Unita (Turin: Einaudi, 2000).

${ }^{20}$ Loreto di Nucci and Ernesto Galli della Loggia, "Introduzione," in Loreto di Nucci and Ernesto Galli della Loggia, eds., Due Nazioni: Legittimazione e Delegittimazione nella Storia dell'Italia Contemporanea (Bologna: Il Mulino, 2003), 1-16.

21 Emilio Gentile, Il Culto del Littorio: La Sacralizzazione della Politica nell'Italia Fascista (Rome: Laterza, 1993), 32; Roberta Suzzi Valli, "Il Culto dei Martiri Fascisti," in Oliver Janz and Lutz Klinkhammer, eds., La Morte per la Patria: La Celebrazione dei Caduti dal Risorgimento alla Repubblica (Rome: Donzelli, 2008), 101-7; Christopher Duggan, Fascist Voices: An Intimate History of Mussolini's Italy (London: Vintage Books, 2012), 51-52.

22 The militarization of society under Fascism meant that paramilitaries and civilians were accorded a similar treatment to the military. 
had "its own fallen and martyrs" was evidence of its efficacy and value as a political force. Across Italy, authorities created dedicated spaces known as the Shrines of Fascist Martyrs (Sacrari dei Martiri Fascisti). ${ }^{23}$ Meanwhile, Fascist exemplars competed with the appeal of anti-Fascist martyrs, such as the murdered socialist Giacomo Matteotti. ${ }^{24}$ Appropriate exemplars who died before the emergence of the movement were cast as "precursors" guiding "humanity ... toward Fascism." 25 In short, the dictatorship sought to hijack existing and potential exemplars by claiming their deaths as sacrifices for the Fascist cause, and also as sources of legitimacy through which the regime might be validated.

While maintaining a high degree of continuity with the past, Fascism also adapted existing concepts to suit new political ends. As the ultimate sacrifice of the individual for the sake of the many, the soldier's death was depicted as the highest incarnation of Fascist collectivism, as an anti-individualistic doctrine that privileged collective interests. In 1925, Mussolini pledged to establish a "totalitarian" state with limitless powers over all aspects of human life, within which individuals would find true freedom by subordinating themselves to the state. ${ }^{26}$ Given that aim, to die in war was no longer simply a necessity, but the highest possible aspiration. As noted by Umberto Eco, all fascist movements share a cult of death, and while "in non-fascist societies, the lay public is told that death is unpleasant but must be faced with dignity," the fascist hero craves death for the cause. ${ }^{27}$

That the fallen soldiers of the First World War occupied a special position is evidenced by an image, promoted by the regime, of Fascism as a "military formation of Living and Dead with at its head the Heroes of the war" (1941). ${ }^{28}$ Different media, including art, architecture, film, literature, and journalism, and various practices such as speeches, rituals, and ceremonies, cast the fallen soldier as an exemplar. For instance, popular literature that appeared after

23 "Se ogni secolo ha una sua dottrina, da mille indizii appare che quella del secolo attuale è il fascismo. Che sia una dottrina di vita, lo mostra il fatto che ha suscitato una fede: che la fede abbia conquistato le anime, lo dimostra il fatto che il fascismo ha avuto i suoi caduti e i suoi martiri," Benito Mussolini and Giovanni Gentile, "Fascismo," in Enciclopedia italiana di scienze, lettere ed arti, vol. 14 (Florence: Treccani, 1932).

24 Stefano Caretti, Matteotti: Il Mito (Pisa: Nistri-Lischi, 1994).

25 "Precursori accumunati dal medesimo destino per guidare l'umanità nel cammino storico dell'era fascisticamente romana," Fuiano, Credo nella Resurrezione, 200.

26 Philip Cannistraro, Historical Dictionary of Fascist Italy (London: Greenwood, 1982), 539 42; Stanley G. Payne, A History of Fascism, 1914-1945 (Madison: University of Wisconsin Press, 1996), 121-23; R.J.B. Bosworth, The Italian Dictatorship: Problems and Perspectives in the Interpretation of Mussolini and Fascism (London: Arnold, 1998), 131-53; and Mussolini's Italy: Life under the Fascist Dictatorship, $1915-1945$ (London: Penguin, 2006), 215-16; Luca Scuccimarra, "Stato totalitario," in Vittoria De Grazia and Sergio Luzzatto, eds., Dizionario del Fascismo, vol. 2 (Turin: Einaudi, 2005): 692-96.

27 Umberto Eco, “Ur-Fascism," New York Review of Books, 22 June 1995, https://www.nybooks. com/articles/1995/06/22/ur-Fascism/ (accessed 28 Nov. 2019).

28 "Schieramento di Vivi e di Morti con alla testa gli Eroi della guerra capitanati dall'Uomo della Storia," in Fuiano, Credo nella Resurrezione, 194. 
the First World War gradually adopted a Fascist idealization of Italy's war dead. ${ }^{29}$ Similarly, schoolbooks, children's literature, and the activities of Fascist youth clubs encouraged the young to admire the fallen and to aspire to their level of sacrifice. While the covers of the copy books used by schoolchildren carried images of young, healthy, and attractive men and women dressed in the uniforms of Italy's armed services, Eco recalls how, at age ten, he received first prize in an essay competition on the basis of a positive answer to the question: "Should we die for the glory of Mussolini?"30

\section{VEHICLES OF EXEMPLARITY}

The Fascist ossuaries that were built to accommodate soldiers who had fallen in the First World War resulted from a campaign to encourage imitation of those soldiers and to create the ossuaries as monuments with "a very high moral content."31 Originally, Italian soldiers who died fighting in 1915-1918 were buried in small cemeteries or mass graves close to the battlefields. However, by the late 1920s, these modest burial places were judged to be insufficient given the aims of Fascist propaganda. Having removed control over the war dead from veterans' groups, local councils, and the Catholic Church, the state set about centralizing the commemoration of the fallen. Hence, the bodies of over three hundred thousand soldiers were disinterred and reburied in roughly thirty new ossuaries that were created in 1929-1939 along former frontlines in northeastern Italy and present-day Slovenia. ${ }^{32}$ The process of reburial concentrated the dead within fewer, and remarkably larger, sites under the control of the military. As a result, the new ossuaries were among the largest war cemeteries in the world. For instance, the ossuary of Redipuglia accommodated the remains of over one hundred thousand soldiers in a vast stepped structure that ascends a hill (image 1). Moreover, a number of the ossuaries were located in, or close to, territories that had formerly belonged to the Austro-Hungarian Empire, and which Italy acquired as a result of the First World War. As markers of newly won land, they were meant "to bear witness, across the centuries, to the heroic sacrifices" of

${ }^{29}$ Carlo Moll, “'Aristocracy of Violence': Countercultural Radicalisation and the Construction of Hegemony in Italian Nationalism and Fascism, 1884-1935," PhD diss., University of Cambridge, 2019.

30 Eco, "Ur-Fascism."

31 "Contenuto morale altissimo," Gen. Federico Baistrocchi, "Discussione del Disegno di Legge: Sistemazione Definitiva delle Salme dei Caduti in Guerra," Atti Parlamentari, Camera dei Deputati (29 May 1931), 5096.

32 Anna Maria Fiore, "La Monumentalizzazione dei Luoghi Teatro della Grande Guerra," PhD thesis, Università Iuav di Venezia, 2001; Lisa Bregantin, Per Non Morire Mai: La Percezione della Morte in Guerra e il Culto dei Caduti nel Primo Conflitto Mondiale (Padua: Il Poligrafo, 2010); Lisa Bregantin and Denis Vidale, Sentinelle di Pietra: I Grandi Sacrari del Primo Conflitto Mondiale (Villorba, Treviso: Biblioteca dei Leoni, 2016). 


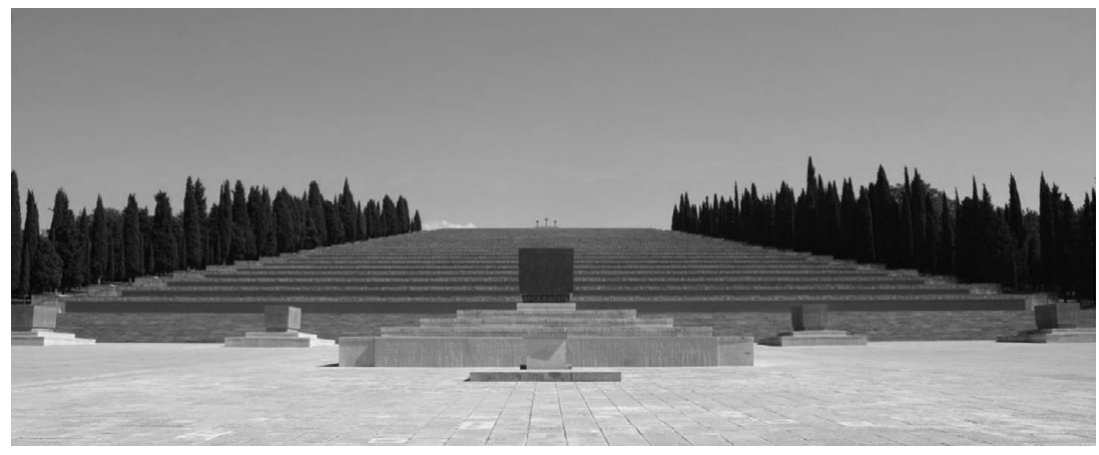

IMAGE 1. Redipuglia, 1938 (author's photo, 2014).

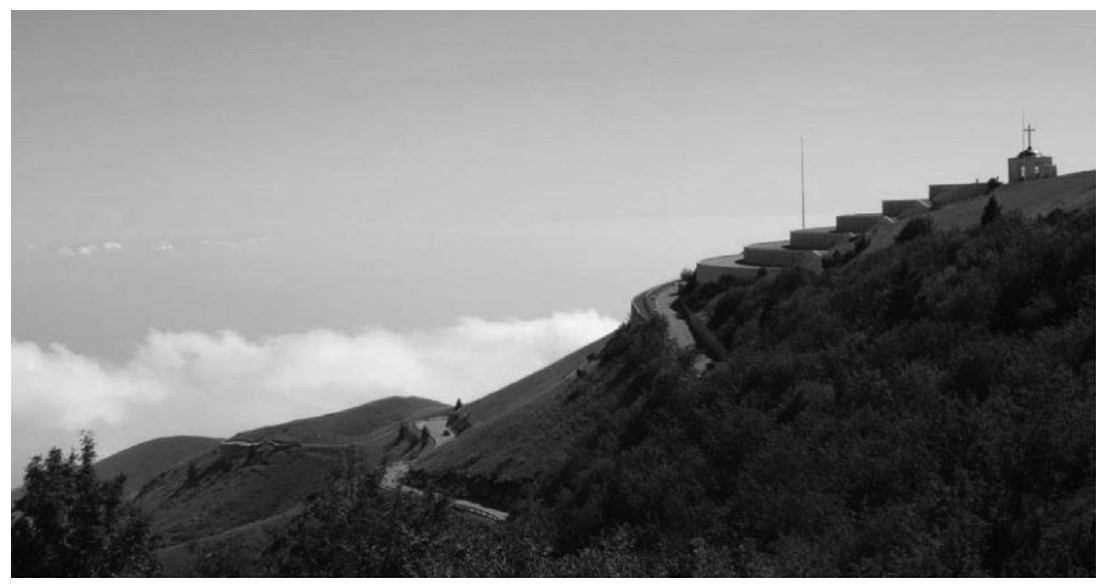

IMAGE 2. Monte Grappa, 1935 (author's photo, 2014).

those "who died serenely ... so Italy could be expanded." ${ }^{33}$ Unique with respect to their size and symbolic power, some of the ossuaries were also sited in evocative, war-torn landscapes. For example, while Monte Grappa is located at an altitude of nearly 2,000 meters, it accommodates the bodies of over twelve thousand Italian soldiers in an ossuary shaped like a tower of Babel, from which it is possible to look down on land indented by bombing (image 2). At Monte

33 "Testimoniare, attraverso i secoli, i sacrifici eroici ivi compiuti" (Archivio Commissariato delle Onoranze ai Caduti, Sezione Tecnica, Montello Disegni, 18 July 1931, Progetto Disegni, Dettagli per la Costruzione, Felice Nori); "Che serenamente morirono ... onde vivesse una più grande Italia" (Archivio Commissariato delle Onoranze ai Caduti, Sezione Tecnica, Fagarè, book 1, fol. 5, Dec. 1930, letter from General Faracovi to the War Ministry, "Richiesta Approvazione del Progetto"). 
Grappa, as elsewhere, the ossuaries combined highly innovative architecture with hints of a medieval fortress. Generally, while the ossuaries vary with respect to planning formats and architectural styles, their architecture consists of a typically Fascist interplay of tradition and modernity, or as a form of modernism with abstract historical motifs.

The removal and reburial of the dead was run by a military commission, which was originally established in 1919 but took on extensive powers in the late 1920 s in order to build the new ossuaries. ${ }^{34}$ The commission was headed by a succession of generals who, from 1935, responded directly to Mussolini. Although the ossuaries reflected the divergent interests of the architects and other individuals involved in their creation, the centralization of power in the hands of the commission, and its close relationship to Mussolini, indicates the importance awarded to the realization of the regime's strategy with respect to its treatment of the fallen. Moreover, the evolution of the ossuaries over the period of their creation (1929-1939) mirrored political developments within a regime that grew in size, and which absorbed power once held by the Church, the monarchy, and other institutions. In fact, while the ossuaries established before 1935 are relatively diverse in terms of their architecture, later projects are more homogeneous and were subject to tighter controls and influences generated by fewer designers, as demonstrated, for example, by the prolonged employment of the partnership between the architect Giovanni Greppi and the sculptor Giannino Castiglioni.

As a vast and costly endeavor, the ossuaries were primarily aimed at promoting the dead as exemplars that might unify the nation, strengthen the regime, and prepare the population for war. Above all, Fascism sought to unite a fractured nation through a shared reverence for the dead. The First World War had been highly divisive in that few Italians had wanted the conflict and many had opposed it. ${ }^{35}$ The death of over a half a million Italians was followed by a disappointing peace treaty, which deepened divisions and destabilized the political system - factors that fueled violence and disorder after 1918 and paved the way for Fascism. Meanwhile, in the immediate postwar period largely private or local initiatives resulted in the construction of monuments to the fallen in squares and streets across Italy. ${ }^{36}$ Ranging between the poles of pacifism and

34 The commission still exists today and is known as the Commissariato Generale per le Onoranze ai Caduti.

35 Antonio Gibelli, La Grande Guerra degli Italiani: 1915-1918 (Milan: Sansoni, 1998), 33334; Patrizia Dogliani, "Constructing Memory and Anti-Memory," in R.J.B. Bosworth and Patrizia Dogliani, eds., Italian Fascism: History, Memory and Representation (New York: St. Martin's Press, 1999), 12; Giovanni Sabbatucci, "La Grande Guerra come Fattore di Divisione," in Loreto di Nucci and Ernesto Galli della Loggia, eds., Due Nazioni: Legittimazione e Delegittimazione nella Storia dell'Italia Contemporanea (Bologna: Il Mulino, 2003); Mario Isnenghi, Le Guerre degli Italiani: Parole, Immagini, Ricordi, 1848-1945 (Bologna: Mulino, 2005), 342-45.

36 Claudio Canal, "La Retorica della Morte: I Monumenti ai Caduti della Grande Guerra," Rivista di Storia Contemporanea 4, 11 (1982): 659-69; Antonello Negri, "Monumenti ai Caduti della Prima 
triumphalism, socialism and nationalism, those monuments emerged from a widespread need to give meaning to the nation's losses, whether viewed as a glorious sacrifice or as a warning against war. While the diversity of those early monuments expressed a lack of agreement among Italians regarding how to remember the conflict, after 1919 many monuments with a pacifist, socialist, or regretful character were destroyed or vandalized by Fascists, who in turn created new monuments imbued with nationalist or triumphalist meanings. This "war of the monuments" ran parallel to the violent nationalists and Fascist attacks against socialist and workers' groups.

\section{UN I T Y}

Having come to power with the promise to unite the nation, the Fascists sought to erase divisions by imposing their own interpretation of the First World War as a triumph. ${ }^{37}$ In that respect, the ossuaries and the use of the fallen soldier as an exemplar helped to promote a positive vision of the war as a glorious victory, which the entire nation had supported. ${ }^{38}$ As a shared admiration for the dead conveyed a sense of common morality, the ossuaries also supported Mussolini's goal to achieve "moral unity" and the integration of Italians into a reconstructed state. ${ }^{39}$ As "brothers in sacrifice," the dead were seen to bind the nation into oneness and to aid the Fascist ambition for a morality under which Italians would be united. ${ }^{40}$

\footnotetext{
Guerra Mondiale: Un'Indagine in Lombardia," Notiziario dell'Istituto Storico della Resistenza in Cuneo e Provincia (1983), 201-24; Renato Monteleone and Pino Sarasini, "I Monumenti Italiani della Grande Guerra," in Diego Leoni and Camillo Zadra, eds., La Grande Guerra: Esperienza, Memoria, Immagini (Bologna: Il Mulino, 1986); Mario Isnenghi, L'Italia in Piazza: I Luoghi della Vita Pubblica dal 1848 ai Giorni Nostri (Milan: A. Mondadori, 1994), 251-58; Vittorio Vidotto, Bruno Tobia, and Catherine Brice, La Memoria Perduta: I Monumenti Ai Caduti Della Grande Guerra a Roma e nel Lazio (Rome: Nuova Àrgos, 1998); Oliver Janz, "Mourning and Cult of the Fallen (Italy)," 1914-1918 Online: International Encyclopedia of the First World War, 4-6, https:// encyclopedia.1914-1918online.net/article/mourning_and_cult_of_the_fallen_italy (accessed July 2018).

37 Claudio Fogu, "Fare Storia al Presente: Il Fascismo e La Rappresentazione Della Grande Guerra," Memoria e Ricerca: Rivista Di Storia Contemporanea 7 (2001): 49-69; Oliver Janz, "Grande Guerra, Memoria della," in Vittoria de Grazia and Sergio Luzzato, eds., Dizionario del Fascismo (Turin: Einaudi, 2005), 627-30; Emilio Gentile, Le Origini dell'Ideologia Fascista (19181925) (Bologna: Il Mulino, 2011).

38 "Decennale della Vittoria," 4 Nov. 1928, quoted in full at http:/www.adamoli.org/benitomussolini/pag0439-.htm (accessed 2 Dec. 2019).

39 The Carta del Lavoro, established on 21 April 1927, states: "La nazione italiana è ... un 'unità morale"; "il Partito ha lo scopo di immettere le masse nello stato al fine di attuare l'unità morale," Dizionario di Politica a Cura del Partito Nazionale Fascista (Rome: PNF, 2014[1940]), 537, 587.

${ }^{40}$ Quote from plaque on the tomb of unknown dead at the ossuary of Montello. Patrizia Dogliani, "Redipuglia," in Mario Isnenghi, ed., I Luoghi della Memoria: Simboli e Miti dell'Italia Unita (Rome: Laterza, 1997); Lucio Fabi, Redipuglia: Storia, Memoria, Arte e Mito Di Un Monumento Che Parla Di Pace (Trieste: Lint, 2002); Hannah Malone, "Redipuglia and the Dead," Mausolus: The Newsletter of the Monuments and Mausolea Trust, summer issue (2015): 26-33; Gaetano Dato, Redipuglia: Il Sacrario e la Memoria della Grande Guerra 1938-1993 (Trieste: Irsml Friuli Venezia
} 


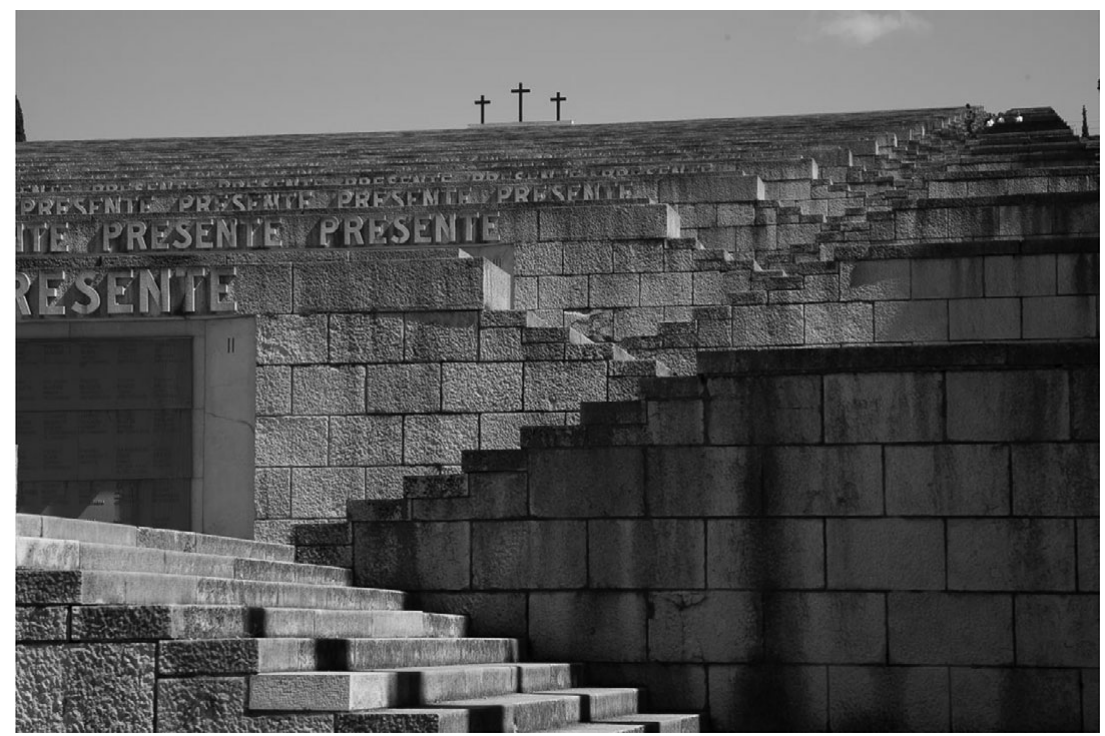

ImAGE 3. Redipuglia, 1938 (author's photo, 2014).

That vision of unity was reflected in the design and organization of the ossuaries. Whereas originally the fallen had been buried in smaller cemeteries with graves differentiated by individual markers, within the ossuaries there was generally little distinction between one set of remains and the next. At Redipuglia, for instance, the remains of over sixty thousand unidentified bodies were massed into crypts, while the remaining forty thousand known soldiers were located in uniform niches within a stepped monolith of white stone. The word presente, which runs along the top of each massive step, is a reference to the Fascist ritual of the rollcall, whereby an officer calls out the names of the dead and their fellow soldiers answer presente, meaning that the dead are ever-present in the memory of the living, and notionally, ever ready to serve (image 3). Against that background of willing obedience, individual identities are largely ignored within the ossuaries, as individuality gave way to the use of exemplars as representatives of Italy's "moral unity." The ossuaries also sidelined those who were seen as unworthy, such as soldiers who had been executed for desertion and whose names did not appear in the official register of deaths, the Albo d'Oro (Golden Register). ${ }^{41}$

National unity was of particular concern where the ossuaries were located on land that had been acquired from Austro-Hungary, and within which the

Giulia, 2015). See also Monica Black, Death in Berlin: From Weimar to Divided Germany (Cambridge: Cambridge University Press, 2010), 98.

41 Bregantin, Per Non Morire Mai, 111. 
regime sought to "Italianize" German-, Ladin-, Croat- and Slovene-speaking inhabitants through a form of "internal colonization" that involved the brutal repression of local languages and cultures. ${ }^{42}$ For instance, Redipuglia, which is now close to the Slovenian border, stands in a region where the majority of men fought with the Austro-Hungarian army. ${ }^{43}$ As a tool in the Fascist campaign of "Italianization," Redipuglia presented the fallen soldier as a model Italian, while excluding from the national community those who fought on the other side. The ossuaries also constituted a warning to local non-Italian and dissident groups in that, for the regime, they represented "an order" to those who might seek to "diminish the immense moral value of our sacrifice," and "an admonishment to the generations that will follow" (1931). ${ }^{44}$

In some ossuaries, enemy soldiers were buried in areas that were separate from those given over to an Italian majority. ${ }^{45}$ Whereas Italians and Austrians were buried together following the wars of Italian Independence of the late nineteenth century, Fascist ideology divided Italians from their adversaries. ${ }^{46}$ That separation reflected a common policy among former belligerent countries in the interwar period, and a tendency to move away from the notion of international solidarity. ${ }^{47}$ Although an international treaty obliged the Italian state to maintain AustroHungarian graves on Italy's soil, these were mostly excluded from Fascist strategies regarding the war dead. One exception was the ossuary at Monte Grappa, which, in addition to over twenty-two thousand Italians, accommodates about ten thousand Austro-Hungarians within a separate area that signals their marginalization. ${ }^{48}$ That tendency to sideline even a former enemy reflected the nature of a Fascist morality, and a separatist ethos based on the rights of Italy as an individual nation rather than universal human values. ${ }^{49}$ In ignoring the principle of international reciprocity, that separatism excluded from moral consideration foreigners and non-Italians within the new territories, and reflected in how the presence of ossuaries aided the forced assimilation of Italy's new citizens.

42 Anna Vinci, Sentinelle della Patria: Il Fascismo al Confine Orientale: 1918-1941 (Rome: Laterza, 2011), 161-68; Roberta Pergher, Mussolini's Nation-Empire: Sovereignty and Settlement in Italy's Borderlands, 1922-1943 (Cambridge: Cambridge University Press, 2017), 12-13.

43 Paolo Rumiz, Come Cavalli che Dormono in Piedi (Milan: Feltrinelli Editore, 2014), 19-21.

44 "Il Governo Fascista vuole che essa sia una imposizione ed un ammonimento: imposizione per quanti abbiano cercato e cercheranno anche solo nel loro animo di sminuire l'immenso valore morale del sacrificio nostro..., e ammonimento per le generazioni che si seguiranno," Gino Peressutti, report on a project to redevelop the cemetery of Colle Sant'Elia, presented on 23 Nov. 1931, quoted in full in Fiore, "Monumentalizzazione," 157.

45 Bregantin, Per Non Morire Mai, 198.

46 Bruno Tobia, Una Patria Per gli Italiani: Spazi, Itinerari, Monumenti nell'Italia Unita (1870 1900) (Rome: Laterza, 1991), 181-200.

47 Gibelli, Grande Guerra, 336-37; Lisa Bregantin and Bruno Brienza, La Guerra Dopo la Guerra: Sistemazione e Tutela delle Salme dei Caduti della Grande Guerra dai Cimiteri al Fronte ai Sacrari Monumentali (Padua: Il Poligrafo, 2015), 21.

${ }^{48}$ Examples also include the ossuaries of Asiago, Pocol, and Casteldante di Rovereto. Fiore, "Monumentalizzazione," 13.

49 Koonz, Nazi Conscience, 5-9, 222. 


\section{STRENGTH}

The ossuaries also used commemoration in a way that supported Mussolini as the nation's primary exemplar. Having ascended to power by undemocratic means, the Duce needed to legitimize his government in the face of entrenched weaknesses in the Italian state and the existence of rival factions. In his speeches, he invoked the moral authority of the fallen whose sacrifices ennobled Fascism as a cause. Equally, the Fascist celebration of the death of "honorable men" helped enhance the regime's image of itself and to generate emotions that were harvested by Mussolini. A text written by a veteran of the First World War, and published as propaganda in 1935, describes how: "Since [the Fascist rise to power] the white bones of our comrades ... rest in peace and their spirits float in the blue sky of Imperial Rome, singing the new songs of the Fatherland." ${ }^{50}$ Seen from this perspective, credit for the ascendency of the dead "into the blue sky" was largely awarded to Mussolini.

Moreover, given that the First World War had exposed limitations in both Italy's military prowess and international standing, the ossuaries contributed to propaganda aimed at restoring the nation's dignity. In that respect, they were said to have inspired a sense of "gratitude towards the Government of Benito Mussolini" for having "been able, alone, to awaken in the soul of each Italian awareness of their moral value and strength by reclaiming the victory [in the war]." 51 As monuments to the "sacrifices and glory of the fatherland," the ossuaries also assuaged an Italian inferiority complex that resulted from a stereotypical image of Italy as a militarily inept nation; an image that was, in part, dispelled through propaganda that depicted Mussolini as the principal exemplar in control of the ossuaries. ${ }^{52}$ In short, the idea that the dead were a source of energy and renewal was captured in an image of how "light irradiates" from the ossuary of Redipuglia "into all the capillaries of national activity" from Mussolini, "to the comrade [and] to the child who is their most ready and secure heir." 53

${ }^{50}$ Arnaldo Geraldini, quoted in Luca De Regibus, Fanti in Trincea (Milan: Lo Prora, 1935), 51; and in Carlo Moll, "Alienation and Community in Italian War Literature, 1918-35," MA thesis., University of Cambridge, 2015. See also: Gibelli, Grande Guerra, 378.

51 "Riconoscenza verso il Governo di Benito Mussolini," Biastrocchi, "Discussione," 5096; "Governo Fascista ... ha saputo, sola, far prosperare e fiorire nell'animo di ogni italiano la coscienza del proprio valore e della propria forza morale, sia attraverso la rivalutazione della vittoria, sia nella rievocazione palpitante della grandezza della stirpe...," Gino Peressutti, report of 23 Nov. 1931, quoted in full in Fiore, "Monumentalizzazione," 157.

52 "Dei sacrifici e della gloria della Patria," plaque at the foot of the monument. See also Vanda Wilcox, Morale and the Italian Army during the First World War (Cambridge: Cambridge University Press, 2016), 144.

${ }_{53}$ "Da Redipuglia si irradia una luce che penetra in tutti i capillari dell'attività nazionale, dal Capo che ne fu anticipatore e camerata al bimbo che ne è l'erede più pronto e sicuro," Fuiano, Credo nella Resurrezione, 157. 
W A R

Another major motivation behind the creation of the ossuaries was their value as a call to arms. In accordance with Mussolini's dictum to "remember [the dead] and prepare [for war]" (ricordare e prepararsi), commemoration and mobilization went hand in hand within Fascist ideology. The regime faced resistance in promoting the principle of military service as tradition dictated that many Italians felt a greater obligation toward their family or community than to the state. ${ }^{54} \mathrm{As}$ a model of self-sacrifice, the fallen soldier popularized the idea of dying for the fatherland, while centuries of military mythmaking depicted that death as the bella morte, or the "good" or "beautiful" death — an ideal that was also infused with a Christian view of martyrdom. ${ }^{55}$ Thus, in reminding the nation that no death is "more beautiful than that of a soldier in battle," a guide to war cemeteries of 1929 reiterated tropes once associated with nineteenth-century Italian patriotism. ${ }^{56}$ However, in contrast to earlier incarnations of Italian nationalism, Fascism cast death in combat as both an act of obedience and the fulfillment of an ideal. War was depicted as a state of being that "increases all human energies to the maximum tension." 57 Thus, war was viewed in the light of a mobilization of the spirit that might pervade the Italian people. In that sense, the military served as an important institution of moral education that advocated "virtue, sacrifice and complete dedication to the [Fascist] Idea." 58 This bellicose rhetoric heightened over the period of 1935-1939 in line with Italy's invasion of Ethiopia, the Spanish Civil War, and the outbreak of the Second World War. While most of the ossuaries were built within that period, some ten days after the inauguration of the ossuary of Monte Grappa in 1935, Italy invaded Ethiopia, at which point one journalist compared the site to a "blazing light that the Nation watches so as to attain, through one victory after another, peace through justice." ${ }^{59}$ Similarly, at the opening of the ossuary of Asiago in 1938, the Chief of the Italian General Staff, Pietro Badoglio, stated that to be "worthy" of the fallen, all Italians "must be ready to follow their example." 60 As such, while

54 Wilcox, Morale, 147.

55 I am grateful to Carlo Moll for sharing the manuscript of his unpublished article, "The Idea of a 'Beautiful Death' in Italian Literature of the Great War.'

56 "Quale più bella, più pura morte sia quella del soldato sul campo?" Giannino AntonaTraversi-Grismondi, "Cimiteri di Guerra," in Il Decennale, X anniversario della Vittoria (Florence: Associazione Nazionale Volontari di Guerra, 1929), 465.

57 "Porta al massimo di tensione tutte le energie umane," Mussolini and Gentile, "Fascismo," 849

58 "Virtù, del sacrificio e della dedizione totale all'Idea," Dizionario di Politica, 613.

59 "L'Ossario del Grappa," Le Vie d'Italia (Nov. 1935): 836-39, quoted in Charles Burdett, "Journeys to the other Spaces of Fascist Italy," Modern Italy 5, 1 (May 2000): 7-23, https://doi. org/10.1080/13532940050003014, 13.

60 "Degni," "si sentano sempre pronti a seguirne il mirabile esempio," Il Comune di Asiago per la Inaugurazione del Monumento ai Caduti: Altipiano dei Sette Comuni (Padua: Tip. del Messaggero di S. Antonio, 1938), 10. 
supporting the Fascist view of war as a source of moral regeneration, the ossuaries promoted Italy's imperialist ambitions and colonial wars.

As already noted, the ossuaries were also instruments of war in that they signaled the subjection of areas gained by Italy after the First World War. In fact, while the press described the ossuaries as sentinels protecting Italy's borders, they were also seen as outposts for future conquests. ${ }^{61}$ For example, three ossuaries that were built in the German-speaking region of South Tyrol/Alto Adige departed from the general program in that they were not located near former battlegrounds but were intended to communicate to local populations that they were under new Italian rule. Hence, for example, the ossuary of Colle Isarco, close to the Brenner Pass, looks like a fortress sited on a major road. In Mussolini's words, the aim was "to let the Tyrolians, the Austrians" know that "all Italians - living and dead — stand ready by the Brenner." 62 One author described the dead warning Italy's enemies that Italians were prepared to fight against invaders. ${ }^{63}$ Significantly, after the assassination of the Austrian chancellor in 1934, Mussolini moved troops to the Brenner Pass in order to discourage a German annexation of Austria. Similarly, whereas the ossuary at Redipuglia was initiated during the Ethiopian war, by the time of its completion in 1938, Europe was heading towards a second global conflict. In fact, propaganda published in 1941 describes Redipuglia as the "spark" that ignited the Second World War and depicts Italian soldiers gathering at the ossuary to march into the Balkans. ${ }^{64}$ Although the influence of propaganda should not be overestimated, the Fascists clearly envisaged the ossuaries as a concrete expression of Italy's "battle cry." 65

\section{MEANS AND MODES}

The benefits that the regime attempted to draw from Italy's war dead determined the symbolic values carried by the architecture and location of the ossuaries, and by the uses to which they were put. Architecturally, those values were realized by means of the organization of forms, spaces, and iconography within the

61 Bruno Tobia, "Dal Milite Ignoto al Nazionalismo Monumentale Fascista (1921-1943)," in Walter Barberis, ed., Storia d'Italia. Annali (Turin: Giulio Einaudi, 2002): 593-642, 642. See also Dogliani, "Constructing Memory," 15.

62 "Noi oggi facciamo sapere ai tirolesi, agli austriaci, al mondo, che sul Brennero c'è in piedi con i suoi vivi e con i suoi morti tutta l'Italia," Atti Parlamentari, Legislatura XXVII, Prima sessione, Discussioni, Tornata del 3 Marzo 1928, Roma 1928, 8361-64, quoted in Klaus Tragbar, "Die Inszenierung der Toten: Italienische Kriegsgräberstätten im Alpenraum als Mittel Faschistischer Propaganda," RIHA Journal 0164 (27 June 2017) 13: http://www.riha-journal.org/articles/2017/ 0150-0176-special-issue-war-graves/0164-tragbar.

${ }^{63}$ Nino Gallimberti, “Gli Ossari di Guerra: L’Ufficio Centrale di Padova per le Onoranze alle Salme," Padova 11 (Nov.-Dec. 1932): 46-60, 57.

64 "Scintilla," Fuiano, Credo nella Resurrezione, 218.

65 Il Comune di Asiago per la Inaugurazione del Monumento ai Caduti: Altipiano dei Sette Comuni, Asiago 1938, 10. This is an anonymously written pamphlet published by the Council of Asiago (Il Comune di Asiago) to commemorate the inauguration of a monument. 
ossuaries. For instance, some designs drew on signs embedded in ecclesiastical architecture in order to imbue the burial of the fallen with a sacred aura. ${ }^{66}$ Plans and spatial structures are generally hierarchical and some, such as Monte Grappa and Redipuglia, are evidently axial. Accordingly, the axial and hierarchical nature of those plans allowed for the prominence of specific exemplars, as evidenced by the placement of the tombs of commanders at the front of the lower ranks in Redipuglia, and the location of the bodies of decorated soldiers within a sarcophagus at the center of the ossuary at Oslavia (image 1). In that they were sited close to former frontlines, the ossuaries contributed to a policy to turn the former battlefields into national monuments, and that symbolism was also underwritten by the location of the ossuaries in frontier regions and on sites whose significance was enhanced by altitude or by landscapes pockmarked by war.

With regard to its capacity to inspire visitors, a guidebook of 1940 describes the ossuary at Monte Grappa as "a symbol, memory, source, example [my italics]." ${ }^{67}$ In addition, choreographed and ritualized forms of use reinforced the value of the ossuaries as political sites of pilgrimage and places in which a nation might honor its dead. School children, veterans, Fascist youth groups, and leisure organizations visited the ossuaries through organized tours. Visitors were expected to "pay grateful homage to the memory of the Fallen" and "take from their heroic sacrifice inspiration and encouragement to love the Fatherland." 68 In particular, the young were encouraged to "draw on the heroic virtues" of the dead. ${ }^{69}$ Expressions of respect were incorporated in rituals and specific actions, as in the act of ascending steep routes and staircases as at Redipuglia. Above all, the rallies and ceremonies that took place in the ossuaries were meant to school Italians in a Fascist morality that accorded the highest merit to death in battle. The nature of that morality, and the manner in which it was transmitted, were expressed in certain practices and bodily actions such as marching, and a pageantry of images and sounds. For example, the inauguration of Redipuglia in 1938 incorporated sensory experiences so as to induce particular feelings. ${ }^{70}$

${ }^{66}$ Hannah Malone, "Architecture, Politics and the Sacred in Military Monuments of Fascist Italy," in Ross Anderson and Maximilian Sternberg, eds., Modern Architecture and the Sacred (London: Bloomsbury, 2020).

67 "Il Grappa è rimasto e troneggia, come simbolo, come memoria, come documento, come esempio," Consociazione Turistica Italiana, Sui Campi di Battaglia: Il Monte Grappa: Guida Storico-Turistica (Milan: Consociazione Turistica Italiana, 1940), 12.

68 "Rendere riconoscente omaggio alla memoria dei Caduti" and "trarre dal sacrificio eroico ... incitamento e sprone a sempre più amare quella patria," "Memoria sulla Sistemazione Definitiva delle Salme dei Militari Italiani Caduti in Guerra" (presented to Mussolini by General Giovanni Faracovi on 11 Mar. 1930), in Leggi, Decreti e Disposizioni Varie Riguardanti il Servizio del Commissariato Generale Onoranze Caduti in Guerra, I (Rome: 1962), 54.

69 Fuiano, Credo nella Resurrezione, 137.

70 “Morti Più Vivi dei Vivi," Il Popolo del Friuli (20 Sept. 1938), 1. See also Dogliani, “Constructing Memory," 15; Fabi, Redipuglia, 28-29; and Dato, Redipuglia, 46. 
As reported in newspapers, the audience heard a "pleasant murmur" from a choir, smelt the smoke from a salvo of guns, and watched the Duce ascend the vast staircase. ${ }^{71}$ At the climax of that ceremony, members of the military shouted presente to indicate they were "ready to be sent anywhere at [the Duce's] orders" 72 Again, that ritual accorded the greatest value to individual sacrifice as a primary factor of a morality that was also popularized through film, pamphlets, newspaper articles, and postcards relating to the ossuaries.

At the same time, the ossuaries demonstrated how exemplars and their noble deeds were publicized by means of "storytelling," as in a narrative that "reveals meaning without committing the error of defining it" (Hannah Arendt). ${ }^{73}$ Under Fascism, stories of exemplary behavior had the capacity to appeal to a range of different individuals. The myths communicated through the ossuaries were also situated within the wider mythology of Fascism. That wider mythology embodied, for instance, the idea that the First World War was a heroic victory, that Fascism was heir to that victory, and that war was a regenerative sacrifice. Moreover, tales about specific exemplars reinforced those broader narratives, which generally gained greater moral weight as they involved a cast of characters to which Italians could relate. In admiring an exemplar, an audience might subconsciously accept the moral premise of a story that distinguished between correct and incorrect attitudes or behaviors. ${ }^{74}$ Equally, the fallen were exemplary precisely because they conformed to long-standing definitions of bravery, loyalty, selflessness, discipline, ruthlessness, and perseverance. The relative familiarity and simplicity of such virtues had the potential to forge "moral unity," or a nation motivated by common values such as patriotic pride and social solidarity. ${ }^{75}$ Hence, Fascism borrowed from known elements of literature and religion to reinforce the image of the fallen soldier, as an exemplar that might be easily absorbed into the public consciousness.

\section{HEROIC EXEMPLARS}

In order to "glorify the epic deeds of our soldiers across the ages," the ossuaries drew on the traditions of epic poetry and ancient tales of heroism, combat, and death. ${ }^{76}$ Such means enhanced the propaganda value of Italy's war dead by elevating some exemplars above others in the same group. For instance,

\footnotetext{
71 “Un murmure soavissimo," Cesco Tomaselli, "L'Omaggio al Condottiero Invitto e ai Centomila di Redipuglia", Il Corriere della Sera (20 September 1938), 2.

72 "Pronti ad essere scagliati ovunque, ai vostri ordini," Tomaselli, "L’Omaggio".

73 Hannah Arendt, Men in Dark Times (New York: Harvest Book, 1968).

74 Koonz, Nazi Conscience, 5.

75 "Unità morale," Dizionario di Politica, 669.

76 "Glorificare nei tempi le epiche gesta dei nostri soldati," Archivio Commissariato delle Onoranze ai Caduti, Sezione Tecnica, Casteldante Rovereto, 14 Mar. 1936, Lettera dal Prefetto di Trento al Commissario Straordinario del Governo per le Onoranze ai Caduti in Guerra (General Ugo Cei).
} 


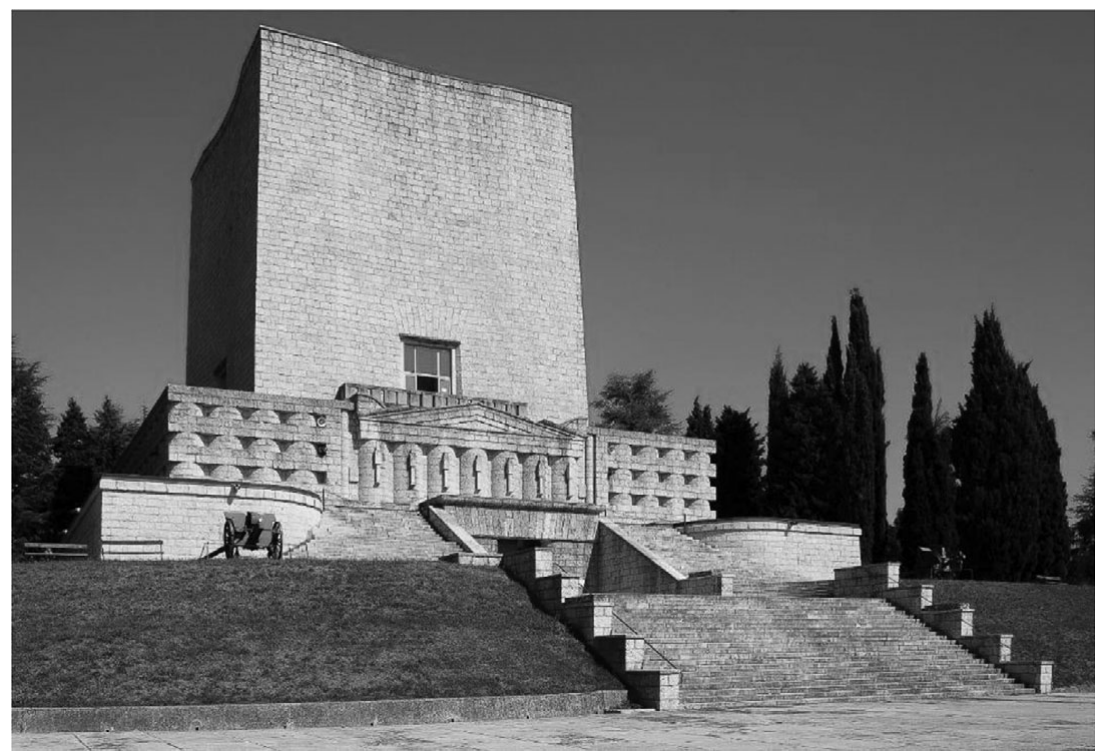

IMAGE 4. Montello, 1935 (author's photo, 2014).

decorated soldiers were singled out as chief exemplars. At the ossuary of Montello, where the remains of over ten thousand soldiers are held within a modernistic fortress built in 1935, special status is given to those who were awarded the Golden Medal for military merit (Medaglia d'oro), in that they are buried in separate niches marked by plaques that record their heroic actions (image 4). Despite the fact that most Italian soldiers were conscripts, accounts of heroism tend to portray the dead as volunteers who willingly died for the cause. For propaganda purposes, lives were meant to be freely given or "donated."77 One soldier is remembered as: "An officer of evident virtue who having learned that his Battalion was engaged in an offensive, voluntarily interrupted his winter leave to run back to his position of honor and danger." 78 Another is described in terms of the importance placed on lives freely given: "Voluntarily enlisted, he

77 “Donata," Giannino Antona-Traversi-Grismondi, "Cimiteri di guerra," in Il Decennale, X Anniversario della Vittoria (Florence: Associazione Nazionale Volontari di Guerra, 1929), 465.

78 "Ufficiale di preclare virtù saputo che il proprio Battaglione era impegnato in una azione, interrompeva volontariamente la licenza invernale ... per accorrere al suo porto d'onore e di pericolo," Archivio Commissariato delle Onoranze ai Caduti, Sezione Tecnica, Montello, b1, f2, "Iscrizioni lapidi," Doc. Ossario del Montello, Specchio Riepilogante il Numero delle Lettere Incise sulle Lapidi dei Caduti, "Nominativi" [Note: Presenta Trascrizione di Cinque Modelli: "Comando Supremo, 4 Novembre 1918," Diaz; "Soldati di Terra e di Mare, Quartier Generale, 24 Maggio 1915"; "Tenente Bongiovanni Emilio Medaglia d'Oro, Montello XIX Giugno"; "Tenente Alessi Guido medaglia d'Oro," Montello XIX Giugno"; "Maggiore Lama Luigi Medaglia d'Oro, 73 Reggimento Fanteria, Montello XX Giugno,” 23 Apr. 1935. 
took part in important actions, always driven by great enthusiasm and love of the fatherland. Although suffering from a fever he wanted to participate in an important offensive with supreme disregard for danger." 79 Similarly, dedication to the national cause is seen to render soldiers careless with regard to their own safety and ready to exhibit a fearlessness that is highly prized: "He was always among the fighters in the most dangerous moments of battle. Finding himself with a division that was thoroughly worn out, whose Commander had fallen, he took control and reassured the men, inciting them to avenge their Captain, and launching them in attack." ${ }^{80}$ Moreover, plaques are evidently intended to inspire future soldiers who might be drawn into war under Fascism: "Having taken Command of the Battalion in particularly critical circumstances he managed with singular skill and the influence of his valorous example [my italics] to drag troops that were already shaken into an attack. He was the first to reach the muchcontested enemy position where he fell stabbed in the heart by an Austrian bayonet." 81

Many of the stories told follow a pattern rooted in epic literature, whereby the warrior meets unsurmountable challenges, perseveres, and finally dies without remorse or fear: "Fighting the enemy hand-to-hand and injured in different body parts by bomb shards, heedless of the pain, he continued to advance always at the head of his men. In a second advance ... he was injured a second time, [and] medicating himself as best as he could, he continued to fight.... Hit for a third time and lethally he fell gloriously in battle." ${ }^{2}$ Thus, these accounts graft onto older traditions of heroism the Fascist ideal of individual sacrifice for collective gain: "Having bravely advanced in reconnaissance among the enemy lines ... he managed to warn [his comrades] of an encircling movement on the right side in time to avoid the trap. Repeatedly hit by a burst of machine guns, he fell gloriously on the field of battle, shouting: 'do not think about me, comrades, always [march] ahead, for the grandeur of Italy." "83 Fundamentally, however, as

\footnotetext{
79 "Volontario di guerra, prese parte ad importanti azioni, animato sempre da grande entusiasmo ed amor di patria. Sebbene febbricitante volle partecipare ad una importante azione, ove, con sommo sprezzo del pericolo," ibid.

80 "Fu sempre fra i combattenti nei momenti più pericolosi della lotta. Trovatosi presso una compagnia assai provata della quale era caduto il Comandante assumeva il Comando e ne incorava gli uomini, incitandoli a vendicare il loro Capitano, poscia li lanciava all'attacco," ibid.

81 "Assunto il Comando del Battaglione in circostanze particolarmente critiche riusciva con singolare perizia e con l'ascendente del suo valoroso esempio a trascinare all'assalto truppe già scosse, ed a giungere per primo sulla tanto contesa posizione nemica ove cadde trafitto al cuore da baionetta austriaca," ibid.

82 "Venuto alla lotta corpo a corpo con l'avversario e ferito in più parti da scheggie [sic] di bomba incurante del dolore sempre alla testa dei suoi uomini continuava ad avanzare. In un secondo sbalzo, combattendo contro nuclei nemici che invano tentavano di fermare l'irruenza e l'impeto dei suoi soldati, rimasto ferito una seconda volta, medicatosi alla meglio continuava a combattere," ibid.

83 "Ripetutamente colpito da una raffica di mitragliatrici, cadeva gloriosamente sul campo, gridando: non pensate a me, avanti sempre, per la grandezza d'Italia compagni," ibid.
} 
moral exemplars all fallen soldiers are seen to share common attributes; notably, stubbornness, optimism, and courage: "Serene, calm, and smiling in the face of danger he was always in an exposed position among his men as a shining example of tenacity and valor." 84

Such stories were tools through which existing and future members of the military were trained to kill and die without hesitation or remorse, and to aspire to the qualities of a warrior. ${ }^{85}$ In that sense, the ossuaries endorsed a morality that legitimized violence and killing in the name of a higher cause. Equally, they promoted a mindset that might be described as masculine and virile, whereas women were expected to look to other Fascist exemplars such as "the unsmiling mother, with dry eyes, who is capable of saying to her son: 'Go and accomplish your duty thoroughly [by dying at war]' but in solitude suffers and waits." 86

Among the fallen of the First World War, famous exemplars also included the "martyrs" of irrendentismo, the nationalist movement that sought the seizure, from Austro-Hungary, of Italy's "unredeemed" lands to the northeast and along the Balkan coast. Born in the Trentino region, the irredentisti Damiano Chiesa, Fabio Filzi, and Cesare Battisti evaded conscription by the Austrian army and enlisted as volunteers with the Italians but were eventually captured by the Austrians and executed as traitors. Told in the traditional terms of martyrdom, their stories became well known and were popularized under Italy's Liberal and Fascist governments as evidence of a patriotism that transcended Italy's borders. Whereas Battisti was buried in a mausoleum in the city of Trento, the remains of Chiesa and Filzi were placed in urns at the center of the ossuary of Rovereto.

While Fascism incorporated different depictions of martyrdom, the ideal hero was devoted to the Romantic model of an almost impossible mission and entertained relatively old-fashioned images of warfare and sacrifice. Plaques at Montello describe scenes of hand-to-hand combat that were rare by the time of the First World War given the emergence of mechanized forms of warfare. $^{87}$ In contrast, Fascist propaganda reflects images of chivalrous encounters with a visible enemy. That outdated image of warfare recalled an earlier group of over two thousand commemorative booklets that were published during, or soon after the First World War by the families of Italy's

84 "Sereno, calmo e sorridente davanti al pericolo sempre esposto in mezzo ai suoi fulgido esempio di tenacia e valore. Colpito per la terza volta ed a morte cadde gloriosamente sul campo," ibid.

${ }^{85}$ In reference to Nazi Germany, see Koonz, Nazi Conscience, 221-22. In general, see Daniel Pick, War Machine: The Rationalisation of Slaughter in the Modern Age (New Haven: Yale University Press, 1996), 202.

86 "La mamma senza sorriso, e con gli occhi asciutti, capace di dire al figliolo: " $v a$ ', compi tutto il tuo dovere fino in fondo" e poi nella solitudine si strugge nel suo dolore e sa attendere," Fuiano, Credo nella Resurrezione, 164.

87 Stefan Goebel, The Great War and Medieval Memory: War and Remembrance in Britain and Germany, 1914-1940 (Cambridge: Cambridge University Press, 2009), 180-94. 
fallen soldiers. ${ }^{88}$ These pamphlets offer an idealized biography of the deceased from childhood to death and were generally in a format akin to that used by the Church to outline the life of a saint. Privately published, they show the degree to which the general public used a rhetoric based on patriotic and spiritualized sacrifice as a means of coping with the loss of immediate family members. They also indicate the existence of attitudes to the fallen that were later coopted by Fascism and adapted to new purposes. Fascism also overlaid such attitudes with adjustments that licensed an air of inhumanity and violence towards the enemy, and an allied conception of the exemplary soldier as a dutiful but ruthless servant to the state. Thus, over time, the image of the martyrs of irrendentismo as exceptional individuals moved toward an image of the obedient soldier, and a willingness both to serve and to die. For instance, a biography of Fabio Filzi published in a magazine in 1917 stresses "the qualities of his intellect and character," and his "enthusiasm" and "patriotic feelings." 89 By contrast, a Fascist pamphlet focuses on Filzi's military skill, and that he declared "I am very happy to die for my Italian Fatherland." 90

Ordinary exemplars could also be elevated among their peers. ${ }^{91}$ For example, an honorable burial was accorded to the "humble peasant" Giuseppe Degol, who returned to Italy from Australia in order to enlist and whose lowly origins and ability to struggle are recorded in the following terms:

Commander of a large selected patrol, he launched himself in attack at the head of his men against a group of enemies in a strong position. Fatally hit in the head, he continued to encourage his men to persevere with the action, and with his heroic example [my italics] and his words, he was able to instill in them so much impetus and audacity that, although in smaller number, they were able to dislodge the enemy and force them flee. Exhausted, he exhaled his last breath while crying "Hurray for Italy"! [Viva l'Italia]. ${ }^{92}$

88 Oliver Janz, "Lutto, Famiglia e Nazione nel Culto dei Caduti della Pima Guerra Mondiale in Italia," in Oliver Janz and Lutz Klinkhammer, eds., La Morte per la Patria: La Celebrazione dei Caduti dal Risorgimento alla Repubblica (Rome: Donzelli, 2008).

89 Illustrazione Italiana, 44, 4 (1917): 78.

90 "Sono felicissimo di morire per la mia Patria italiana," Comitato Nazionale per le Onoranze ai Martiri del 1916, I Martiri del 1916: Cesare Battisti, Damiano Chiesa, Fabio Filzi, Giovanni Grion, Francesco Rismondo, Nazario Sauro (Milan: Adriatico Nostro, 1926).

91 "Umile contadino," Archivio Commissariato delle Onoranze ai Caduti, Sezione Tecnica, Casteldante Rovereto, Rovereto archivio, ca. 27 July 1931, Faracovi, "Promemoria," 2.

92 "Comandante di una grossa pattuglia scelta, si slanciava alla testa dei suoi uomini all'attacco di un nucleo di nemici in forte posizione. Colpito mortalmente al petto, continuò ad incitare $i$ suoi uomini a perseverare nell 'azione, e col suo esempio eroico e con la sua parola, seppe infondere in essi tanto slancio ed ardire, che essi, sebbene di gran lunga inferiori di numero, in un nuovo e più furioso assalto, riuscirono a sloggiare il nemico ed a volgerlo in fuga. Esausto, esalava l'ultimo respiro al grido di Viva 1'Italia!" Gaetano Carolei, Giudo Greganti, and Giuseppe Modica, 
In contrast to the nineteenth century, when the same final words were attributed to heroes of the Risorgimento, Degol was depicted as an obedient soldier rather than as a unique individual. ${ }^{93}$

Under Fascism, the unnamed majority evidently outweighed the number of "named" exemplars, decorated soldiers, and famous martyrs. That undifferentiated mass was loosely represented by the foot soldier (fante) - a symbolic figure that emerged prior to Fascism as the result of efforts to democratize the remembrance of fallen soldiers, but which was later coopted as an element of Fascist mythmaking. Fascist propaganda describes the foot soldier as "the warrior with formidable muscles, flashing eyes and a brutal force who is able to resist all other forces." "He stands out within the "immense army of the fallen" as the epitome of soldierly virtues. ${ }^{95}$ Although he is "good and gentle," he transforms on the battlefield into a killing machine, and his willingness to sacrifice his own life gives him the right to kill his enemies without mercy. ${ }^{96}$ Behind this image lies that of the most celebrated soldier of the dictatorship; namely Mussolini, who served in the First World War as a marksman before being wounded in a training accident in 1917. In contrast to Mussolini, the Italian foot soldier is an "everyman" and is akin to the anonymous figure of the Unknown Soldier to whom monuments were erected in cities across Europe in 1920-1921. ${ }^{97}$ However, while that image of the foot soldier emerged after the First World War as a symbol of the rights afforded to common soldiers, in Italy the notion of anonymity reflected the Fascist ideal of a private life that was subordinated to the public good. Thus, the identity of the Fascist foot soldier is as a member of the military, rather than as a son, father or husband. Nevertheless, although ordinary, the Italian foot soldier is also special, which reflects the ambivalence highlighted by Paolo Heywood (this CSSH issue) with respect to exemplars, which are typical of a general category but possessed of special qualities.

In Italy, the status awarded to the foot soldier reinforced, rather than reduced, a tendency toward elitism. For example, three Italian generals of the First World War, who later held positions in the Fascist regime, were granted the honor of burial within the ossuaries even though they died of natural deaths years after the conflict. ${ }^{98}$ Their exemplarity served a different purpose, which was to

Le Medaglie d'Oro al Valore Militare dal 1915 al 1916 (Rome: Gruppo Medaglie d'Oro al Valore Militare d'Italia, 1968), 128.

${ }^{93}$ For instance, in 1844 the Bandiera brothers reportedly cried "Viva l'Italia" before they were executed for their role in a failed rebellion.

94 Fuiano, Credo nella Resurrezione, 64.

95 “Immenso esercito dei morti," Fuiano, Credo nella Risurrezione, 153.

96 "Buono e mite," ibid., 166-67.

97 Laura Wittman, The Tomb of the Unknown Soldier, Modern Mourning, and the Reinvention of the Mystical Body (Toronto: University of Toronto Press, 2011).

98 This was the case with General Gugliemo Pecori Giraldi, General Gaetano Giardino, and the Duke of Aosta, General Emanuele Filiberto di Savoia. 
support the Fascist principles of hierarchy and leadership. In contrast to the foot soldier, the generals were seen to be extraordinary. Thus, while the fallen were generally deemed worthy of imitation, there were important differences between the celebration of dutiful soldiers as a laudable mass, and of leaders as unique individuals. Meanwhile, there were also other variations: for example, survivors of the First World War were singled out when, in claiming to represent the interests of veterans, the regime looked to former combatants as possible recruits, and as exemplars whose continued presence had propaganda value. Such veterans included the "Grande Mutilato" Carlo Delcroix, who having lost his hands and sight in the First World War became an icon of the regime as a member of the Fascist government and President of the Association of disabled ex-Servicemen (ANMIG).

\section{RELIGIOUS EXEMPLARS}

The Fascist categorization of the fallen soldier as an exemplar overlapped with that of the religious martyr and followed an older tendency to promote the First World War as something akin to a holy crusade, or sacred mission. ${ }^{99}$ This reflected a convergence of politics and religion, or a "sacralization of politics" as a process whereby, from the late 1700 s, Italian nationalism borrowed strategies from the clergy, and the sacred migrated from the religious to the political sphere. In effect, Fascist ideology was conceptualized as a faith. ${ }^{100}$ Under conditions in which the decline of religious authority ran together with an expansion of the state, Fascism sought to supplant Catholic morals with a code that favored the regime, and which depicted its cause in religious terms. ${ }^{101}$ When, in 1925, Mussolini established the Albo d'Oro, the roll of honor that bore the names of fallen Italian soldiers, he declared its pages to be "as sacred as Christ's Gospel," thereby casting Fascism as a "political religion" founded, in part, on the sacredness of the fallen. ${ }^{102}$

At the same time, the Fascist institutionalization of remembrance also reflected a rapprochement between Church and state. The Lateran Pacts of 1929 , which officially allied the dictatorship to the Vatican, were meant to resolve conflicts between secular and clerical authorities dating back to the Risorgimento. In reality, this was a marriage of convenience dictated by mutual

\footnotetext{
${ }^{99}$ Goebel, Great War, 90.

100 Gentile, Il Culto del Littorio: La Sacralizzazione della Politica nell'Italia Fascista (Rome: Laterza, 2009), 9, 303-5; Emilio Gentile and Robert Mallett, "The Sacralisation of Politics: Definitions, Interpretations and Reflections on the Question of Secular Religion and Totalitarianism," Totalitarian Movements and Political Religions 1, 1 (2007): 18-55. However, this conception of Fascism had little bearing on the actual workings of the state.

101 Koonz, Nazi Conscience, 4-5.

102 "Queste pagine sono sacre come quelle del Vangelo di Cristo," quote of 1925 in Bregantin, Per Non Morire Mai, 248-49.
} 
self-interest rather than ideological alignment. Thus, tensions emerged as Fascism encroached on the domain of the Church and threatened the autonomy of the clergy. ${ }^{103}$ As a facet of Italian life that was commandeered by the regime, the commemoration of the war dead became a source of rivalry between the Fascist and clerical powers, although, in exchange for backing the regime, the Catholic Church was granted a role in the main rituals of Fascist commemoration. ${ }^{104}$

Meanwhile, Catholicism was a fruitful source of images and concepts through which the regime promoted the fallen soldier as an exemplar. For instance, the ossuaries were officially called shrines (sacrari) because they gathered "the mortal remains of our Martyrs." 105 The traditional, and often bloodied image of the religious martyr was largely secularized through nationalist narratives of the nineteenth century. ${ }^{106}$ In turn, religious imagery and a militaristic rhetoric of aggression came together during the First World War, as the Catholic Church supported the Italian state through initiatives aimed at harnessing a religious sense of duty to the war effort. ${ }^{107}$ Under Mussolini, however, the traditional paradigm of Christian martyrdom was resurrected insomuch as it was appropriate to Fascism as an ideology based on death and sacrifice. ${ }^{108}$

The creation of shrines dedicated to Fascist martyrs within churches, such as that of Santa Croce in Florence, demonstrates how Fascism attempted to benefit from associations with Catholicism. Similarly, within the ossuaries, the exemplarity of the fallen soldier drew on the image of Christ as a figure sacrificed, and as a major symbol of martyrdom. At Redipuglia three large crosses, located at the top of the giant staircase, symbolize the "Calvary" of the fallen (image 4). Equally, at Pian di Salesei, the ossuary rises from a plan that is arranged in the shape of a cross, and while the blocks that make up the cross represent battles in the surrounding area, the deaths associated with those battles

103 John F. Pollard, The Vatican and Italian Fascism, 1929-1932: A Study in Conflict (Cambridge: Cambridge University Press, 1985), 1-6, 104, 167-68, 191.

104 Dogliani, "Constructing Memory," 15; Oliver Janz, "Mourning and Cult of the Fallen (Italy)," 1914-1918 Online: International Encyclopaedia of the First World War, 4, https:// encyclopedia.1914-1918-online.net/article/mourning_and_cult_of_the_fallen_italy; Hannah Malone, "Monte Grappa: Il Sito, il Sacrario e la Memoria," in Per Non Dimenticare: Sacrari del Novecento, Maria Grazia D’Amelio, ed. (Rome: Accademia di San Luca, 2019).

105 “L'Ossario infatti raccoglierà le spoglie mortali dei nostri Martiri," Archivio Commissariato delle Onoranze ai Caduti, Sezione Tecnica, Cimone di Tonezza, Relazione tecnica, ca. 1929.

106 Brad S. Gregory, Salvation at Stake: Christian Martyrdom in Early Modern Europe (Cambridge: Harvard University Press, 2009); Paul Middleton, Martyrdom: A Guide for the Perplexed (London: T \& T Clark International, 2011); Jolyon Mitchell, Martyrdom: A Very Short Introduction (Oxford: Oxford University Press, 2012); Michaela DeSoucey et al., "Memory and Sacrifice: An Embodied Theory of Martyrdom," Cultural Sociology, 1 Mar. 2008, https://doi.org/ 10.1177/1749975507086276.

107 Fussell, Great War, 22; John Gooch, The Italian Army and the First World War (Cambridge: Cambridge University Press, 2014), 163.

108 Roger Griffin, The Nature of Fascism (London: Pinter, 1991), 32-36. 
are cast as necessary sacrifices on the path to national salvation. Official publications also compared the mythical foot soldier to Christ as a messianic figure, who died under comparable conditions, in that both Christ and the fallen soldier "saved humanity ... died for Redemption ... gave us a religion, [and] began a new era." 109

Following an Italian tradition of sacri monti, or up-hill pilgrimages sites, visitors to the ossuaries were meant to endure pathways that were physically taxing in order to express their indebtedness to the dead and faith in the nation for which lives were lost. For one author, the soldiers buried in the ossuaries were akin to saints because their "sacred function is to keep patriotism alive among Italians." 110 For another, the role of the dead was that of "apostles of the religion of the fatherland." 111 Similarly, as "chosen souls" the fallen were thought to enjoy a state of grace or enlightenment. ${ }^{112}$ Thus, the idea that Italians should follow the example of the fallen, and embrace a spirit of sacrifice, is akin to the concept of Imitatio Christi as established in the medieval book of devotion attributed to Thomas à Kempis.

In order to encourage emulation, it was also crucial that exemplars were seen to be rewarded by means of their position within the national memory. ${ }^{113} \mathrm{In}$ that sense, the regime's view of exemplars can be examined in the light of how they were viewed by Italians who responded perhaps with enthusiasm, admiration, disgust, or indifference. Due to the difficulties of accessing sources, knowledge of individual responses is necessarily limited, and restrictions on freedom of expression due to censorship cast doubt on the veracity of sources that are available. Thus, it is difficult to gauge the success of the ossuaries in terms of the promotion of a genuine admiration for fallen soldiers. It is also hard to distinguish between reactions engendered by the regime and those that sprang from the nature of bereavement and the emotional needs of mourners. Nonetheless, recruitment under Fascism drew heavily from a generation of men who had been too young to enlist in the First World War, and some of those recruits joined the Fascist squads to compensate for that missed experience. ${ }^{114}$ Equally, the popularity of war literature in this period suggests that some men did fall under

109 "Tutti e due salvarono l'umanità ... tutti e due morirono per una Redenzione ... tutti e due ci dettero una religione, tutti e due iniziarono una nuova era," Fuiano, Credo nella resurrezione, 152.

110 "Continueranno nei secoli la funzione sacra di tener desto negli Italiani l'amore alla Patria," Gallimberti, "Gli Ossari di Guerra,” 60.

111 “Apostoli della Religione della Patria," Fuiano, Credo nella Resurrezione, 153.

112 "Spiriti eletti," Baistrocchi, "Discussione," 5096.

113 Claudio Canal, "La Retorica della Morte: Monumenti ai Caduti della Grande Guerra," Rivista di Storia Contemporanea 4, anno XI (Oct. 1982): 659-69, 661-62; Laqueur, Work of the Dead, 412; Wilcox, Morale, 163.

114 Matteo Millan, “The Contradictions of Veterans' Associations? The Fascist Appropriation of the Legacy of World War I and the Failure of Demobilisation," in Alessandro Salvador and Anders Granås Kjøstvedt, eds., New Political Ideas in the Aftermath of the Great War (Springer: New York, 2017), 87-108, 95-96. 
the spell of heroic exemplars. It is also the case that, in general, the narratives associated with exemplars varied because they were promoted by different bodies of the Fascist state, the Party, related associations, and the official and unofficial media. Those narratives also took on different meanings as individuals tailored exemplars to suit their own needs and beliefs. Thus, to some extent, the fate of the fallen soldier as an exemplar was the product of a mass of individual reactions and interpretations on the part of the Italian people, and of a medley of adjustments made to propaganda as promoted by Fascism.

\section{INTERNATIONAL COMPARISONS}

Although Fascist exemplarity drew on distinctly Italian traditions, beyond Italy, most (although not all) fascist movements looked to the use of exemplars, especially in relation to the dead. In particular, given that Hitler's regime had strong ideological, cultural, and political ties with Mussolini's, parallels emerged between the use of exemplars in Italy and Germany. As in Fascist Italy, National Socialism promoted a morality that highlighted the importance of the German nation and the role of the individual in relation to the state. Fallen soldiers of the First World War occupied a special role as martyrs harvested by Nazism. ${ }^{115}$ Equally, a cult of the dead was reinforced by religious and political narratives that promoted war, heroism, duty, morality, and manhood. In casting the fallen as a life force of the German nation, the Hitler Youth proclaimed: "The best of our people did not die so that the living might die, but that the dead might come alive." 116 As with the Italian fante, the anonymous infantry soldier, or Landser, became a German icon. However, in this realm there were subtle differences between National Socialism and Italian Fascism, for instance with respect to the use of religious imagery in Italy. Although Germany embraced the idea of the soldier as martyr and savior, the emphasis on Christian symbols was less pronounced. ${ }^{117}$ Moreover, whereas Mussolini's pact with the Vatican allied religion to political martyrdom, National Socialism endorsed a secular cult of the dead that restricted or excluded the role of the clergy within commemorative practices, a sign of Nazism's relative independence from religious institutions. In comparison to German Protestants, Italian Catholics were also more inclined to venerate the war dead as figures akin to religious martyrs.

\footnotetext{
115 George Mosse, "National Cemeteries and National Revival: The Cult of the Fallen Soldiers in Germany," Journal of Contemporary History 14, 1 (1979): 1-20; Jay Baird, To Die for Germany: Heroes in the Nazi Pantheon (Bloomington: Indiana University Press, 1992); Sabine Behrenbeck, Der Kult um die Toten Helden: Nationalsozialistische Mythen, Riten und Symbole 1923 bis 1945 (Vierow: SH-Verlag, 1996); Monica Black, Death in Berlin: From Weimar to Divided Germany (Cambridge: Cambridge University Press, 2010), 69-110; Paul Betts, Alon Confino, and Dirk Schumann, eds., Between Mass Death and Individual Loss: The Place of the Dead in TwentiethCentury Germany (Oxford: Berghahn, 2011).

116 Mosse, "National Cemeteries," 6.

117 Ibid., 4-5.
} 
From the early 1930s, the German War Graves Commission (VDK or Volksbund Deutsche Kriegsgräberfürsorge) created Totenburgen, or "fortresses of the dead," to accommodate German soldiers who fell in Central Europe and the Balkans. ${ }^{118}$ Three months before Italy and Germany were linked by the Rome-Berlin Axis of 1936, an agreement between the two governments led to the creation of five German Totenburgen in northern Italy. They were comparable to their Italian counterparts in form and intent, insofar as they adopted monolithic architectural formats and functioned as sites that Germans were encouraged to visit. However, while the architecture of the Italian ossuaries generally reflected an attachment to styles that were both historicist and yet modernistic, the art and architecture of their German equivalents tended to be more historicist and conservative, and to carry stronger references to the Middle Ages and medieval chivalry. For instance, the German ossuary at Quero (19361939), although on Italian soil, was built in the style of a medieval fortress with traditional and naturalistic depictions of robust soldiers. In effect, the Totenburgen reflected Nazi Germany's rejection of modernism and the control the state exerted over art and architecture that were intended to legitimize Nazism by means of evidently historical references. Still, although different in style, both the German and Italian ossuaries resulted from the ambition to use the fallen soldier as an exemplar with a view to satisfying political and ideological demands.

\section{CONCLUSIONS}

Fascism embodied a sense of morality that justified the use of force and coercion, encouraged obedience, and promoted acceptance of the primacy of the state. That morality was suited to the use of exemplars, and particularly of the fallen soldier, whose value to the state was such that it resulted in the creation of the Fascist ossuaries. While every society has its own exemplars, Italy's Fascist regime was particularly reliant on exemplarity as a political tool. In that respect, the image of the fallen soldier was fashioned to support an ideology that was:

118 Monika Kuberek, "Die Kriegsgräberstätten des Volksbundes Deutsche KriegsgräberFürsorge," in Michael Hütt and Jonas Verlag, eds., Unglücklich das Land, das Helden Nötig Hat: Leiden und Sterben in den Kriegsdenkmälern des Ersten und Zweiten Weltkrieges (Marburg: Jonas, 1990); Gunnar Brands, "From World War I Cemeteries to the Nazi 'Fortresses of the Dead," in Joachim Wolschke-Bulmahn, ed., Places of Commemoration (Washington, D.C.: Dumbarton Oaks, 2001); Stefan Goebel, The Great War and Medieval Memory (Cambridge: Cambridge University Press, 2009), 36-37, 102-3; Marco Mulazzani, "Il Memoriale Germanico a Pinzano al Tagliamento del VDK, 1938-1943," in Paolo Nicoloso, ed., Le Pietre della Memoria: Monumenti sul Confine Orientale (Udine: Gaspari, 2015), 175-200; Christian Fuhrmeister, "Robert Tischler, Chefarchitekt 1926-1959: Ein Desiderat," RIHA Journal, special issue "War Graves, War Cemeteries, and Memorial Shrines as a Building Task (1914 to 1989), Die Bauaufgabe Soldatenfriedhof/Kriegsgräberstätte zwischen 1914 und 1989," Christian Fuhrmeister and Kai Kappel, eds. (2017), https://www.rihajournal.org/articles/2017/0150-0176-special-issue-war-graves/0159-fuhrmeister. 
(a) ill-defined and inconsistent; (b) polarizing and divisive; (c) based on an epic vision of nationalism and renewal; and (d) demanded subservience to the Fascist leadership. Thus, those who died for the nation were depicted as warriors and martyrs, and used to epitomize heroism, obedience, violence, and sacrifice. Meanwhile, in constructing an image of the fallen, Fascism drew on history and precedents, such as those borrowed from the Risorgimento and the Church, but it also shaped each exemplar by means of new devices and immediate political needs and, in the case of the fallen soldier, in line with the model of the Duce as the prime exemplar.

While the ossuaries concentrated the remains of the war dead in a homogenized mass of similar "cells," they were also places where architecture and art served to concretize and exploit the meanings attached to the fallen. Equally, certain uses, practices, and ceremonies acted as ritualized forms of propaganda that drew on history, religion, and political traditions, and on symbolism that could be ancient and modern. Both the physical and functional aspects of the ossuaries carried meanings borrowed, for example, from epic poetry, European Romanticism, and Catholicism. Whether as martyrs or as warriors, the dead were presented as paradigms of obedience, discipline, faith, sobriety, social solidarity, disdain of materialism, and respect for authority, and ultimately as heroes who were willing to die for the benefit and glory of Italy and Fascism. ${ }^{119}$ Moreover, in that they helped attribute moral value to the core myths of Fascist ideology, the fallen became key sources of political and moral legitimacy. The war dead were thus used to support efforts to unify and strengthen Italy, and to prepare Italians for war. In appealing to values such as loyalty and selflessness, idealism and patriotism, Fascism turned traditional and "positive" qualities towards militaristic ends. In that respect, a Fascist morality emerged on the back of adjustments made to the definition and interpretation of established virtues.

Finally, exemplarity continues to be a chief facet of political and religious ideologies, culture wars, and social conflicts that revolve around factors such as racism and gender equality. It is expressed in the current struggle to either destroy or protect certain statues and monuments, and to commemorate or expel from history figures associated, for example, with colonialism and slavery. It also runs through the naming and renaming of streets and urban spaces. In that respect, its importance can also be traced through the evolving reactions of populations, such as those of Italy or Germany, to monuments and urban projects inherited from regimes whose ideologies have been largely rejected. Equally, it is evident in the attempts, for example, of far-Right movements to defend the existence of such monuments. Essentially, there is the question of who deserves exemplary status. As in the case of the "monuments war" that erupted in Italy after the First World War, clashes continue to be fought between different conceptions of

119 Koonz, Nazi Conscience, 3, 133. 
morality. In Italy, Fascist exemplars still exist as part of the cultural and political fabric of the country. Since 2017, Italian neo-fascist groups have met every year in order to commemorate "Fascist martyrs" at a chapel built by Mussolini within Rome's Verano Cemetery for those who gave their lives for the regime. ${ }^{120}$ At the same time, the growth of anti-racist activism across the globe is empowering calls within Italy for the demolition of monuments associated with Fascism and colonialism, including those that commemorate the Fascist governor of Somalia, Rodolfo Graziani, and the journalist Indro Montanelli. ${ }^{121}$ On both sides of the political divide, Fascist exemplars are still inspiring calls to action. Thus, an understanding of how exemplarity is tied to fascist tendencies might be used as a basis on which to examine their ongoing appeal, especially to particular sections of Italian society and those of other countries.

\begin{abstract}
This article aims to dissect the nature of exemplarity in Italian Fascism. The social and political structures that emerged in Fascist Italy were highly reliant on a sense of morality, largely because of the degree of violence inherent in those structures. Under Fascism, morality was founded on concrete examples rather than on abstract principles. Exemplars were idealized sources of moral strength, and figures with the capacity to inspire or persuade. In particular, the fallen soldier and those who died for the nation constituted a major category of Fascist exemplars. Thus, soldiers who fell in the First World War were awarded exemplary status in order to encourage behaviors favorable to the regime. With the goal to demonstrate the importance awarded to exemplars, this paper focuses on a group of ossuaries, or bone depositaries, that were built under Mussolini's dictatorship, and within which the regime reburied the remains of soldiers who fell in the First World War. The main purpose of the ossuaries was to present the dead as role models that might boost support for a program of nationalism, militarism, and imperialism. Thus, while their creation drew on factors such as Romantic literature and Italy's religious and political traditions, the ossuaries represent an ideal case study of how Fascist morality was aided by and expressed through the use of exemplars.
\end{abstract}

Key words: Fascist Italy, morality, death, cemeteries, exemplarity, Mussolini

${ }^{120}$ Susanna Turco, "Il Sottosegretario Luigi Gaetti (M5S) Parla di «Martiri Fascisti»," L'Espresso, 11 Jan. 2019, https:/espresso.repubblica.it/attualita/2019/01/11/news/martiri-fascistisottosegretario-1.330387.

${ }^{121}$ Igiaba Scego, "Cosa Fare con le Tracce Scomode del Nostro Passato," Internazionale, 9 June 2020, https://www.internazionale.it/opinione/igiaba-scego/2020/06/09/tracce-passato-colonia lismo-razzismo-fascismo; Alessandro Robecchi, "Graziani. La Statua del Boia Fascista Va Rimossa: Ė una Vergogna Nazionale," Il Fatto Quotidiano, 10 June 2020, https://www.ilfattoquotidiano.it/inedicola/articoli/2020/06/10/graziani-la-statua-del-boia-fascista-va-rimossa-e-una-vergogna-nazio nale/5829924/; Silvia Ballestra, "Montanelli Non Merita una Statua," Internazionale, 16 June 2020, https:/www.internazionale.it/opinione/silvia-ballestra/2020/06/16/statua-montanelli. 